\title{
The homestead as fortress: Fact or folklore?
}

\author{
Heather Burke, Lynley A. Wallis, Bryce Barker, Megan Tutty, \\ Noelene Cole, lain Davidson, Elizabeth Hatte and Kelsey Lowe
}

\section{Introduction}

Houses are quintessential statements of identity, encoding elements of personal and social attitudes, aspirations and realities. As functional containers for human life, they reflect the exigencies of their construction and occupation, as well as the alterations that ensued as contexts, occupants and uses changed. As older houses endure into subsequent social contexts, they become drawn into later symbolic landscapes, connoting both past and present social relationships simultaneously and connecting the two via the many ways they are understood and represented in the present. As historical archaeologist Anne Yentsch has argued: 'Many cultural values, including ideas about power relationships and social inequality, are expressed within the context of the stories surrounding houses'. ${ }^{1}$ This paper is one attempt to investigate the stories surrounding a ruined pastoral homestead in central northern Queensland in light of relationships between non-Aboriginal and Aboriginal people on the frontier.

The stone ruins of Cambridge Downs homestead (Figure 1) are situated on the banks of the Stawell River in the Burke District of central north Queensland, approximately 30 kilometres north-west of the township of Richmond (Figure 2). Cambridge Downs was first established in 1864, at a time when pastoralists were expanding into much of north and west Queensland. The station continued to operate until the end of World War II, when it was divided and re-leased as part

1 Yentsch 1988: 11 
of the soldier settlement scheme. ${ }^{2}$ In celebration of Cambridge Downs's history as a foundational European settlement for the region, the Richmond Shire Council opened a replica of the homestead in the town of Richmond in 2009 (Figure 3).



Figure 1: Ruins of Cambridge Downs homestead, 2016, looking south-west.

Source: Photograph by Heather Burke.

In an area where the vernacular architecture of pastoralism - both initially and later - was typified by timber and tin, the stone building at Cambridge Downs is certainly unusual. The public interpretive materials at the replica present the structure in a decidedly military light:

The stone walls would not be easily breached, and the windows had iron bars to defend against Aboriginal attacks. The siting of the homestead, well out on a clear flat 300 metres away from the wooded Cambridge Creek, is supporting evidence of the pioneer's [sic] defence strategy. ${ }^{3}$

Other versions of this theme are more elaborate:

The need to take precautions against native attack was fundamental when the Cambridge Downs homestead was built ... The walls were of local flagstone rock mostly up to three centimetres thick laid horizontally and cemented one above the other in a wall 30 to 40 centimetres thick and about two metres high. Windows were square openings without glass but with vertical iron bars two and a half centimetres thick. Doors were solid timber swung on solid timber frames. ${ }^{4}$

Authurs 1995: 268.

Richmond Shire Council n.d. (a).

Tourism and Events Queensland n.d.: 106. 


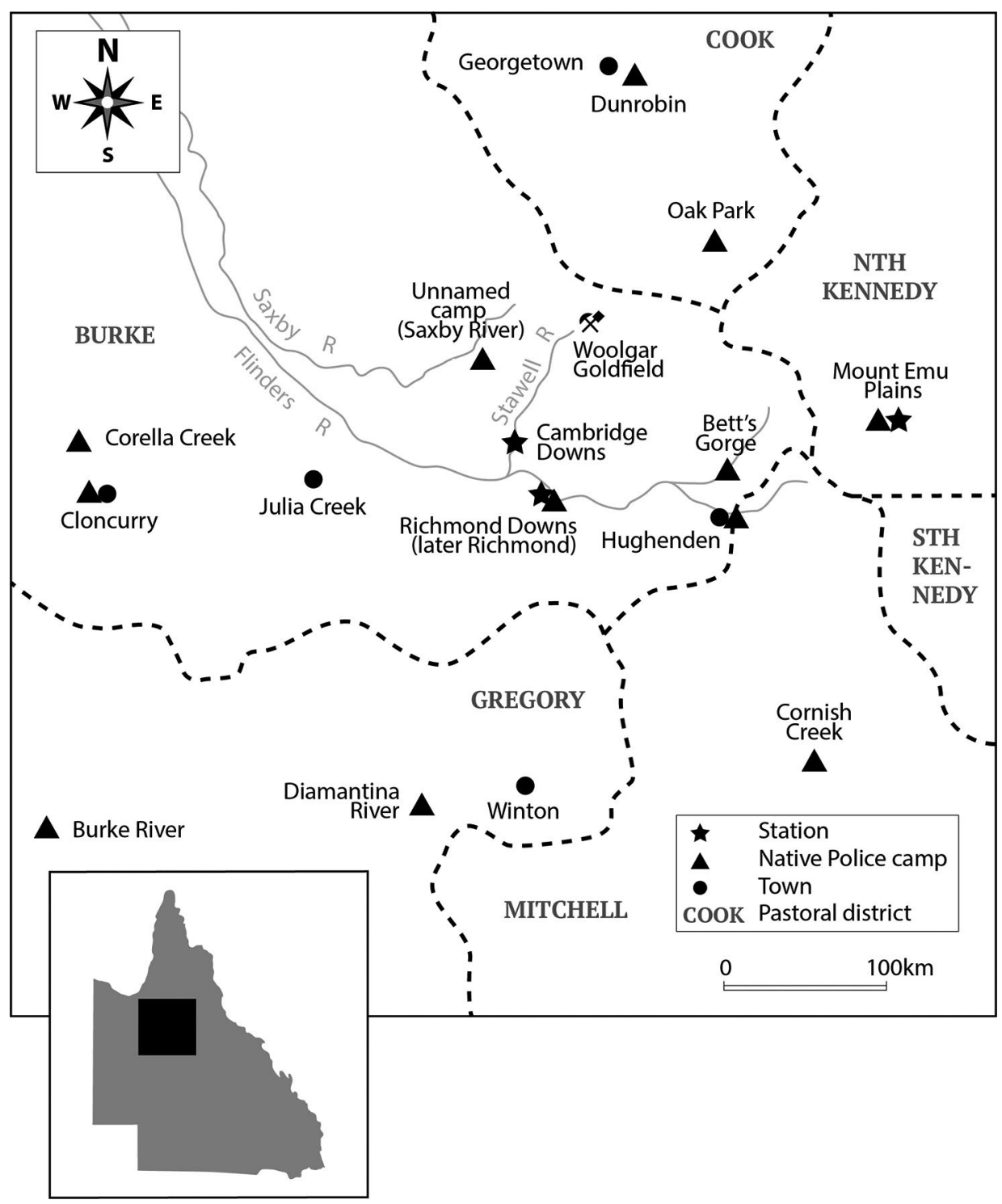

Figure 2: Location of Cambridge Downs and other places referred to in the text. Source: Map created by the authors. 


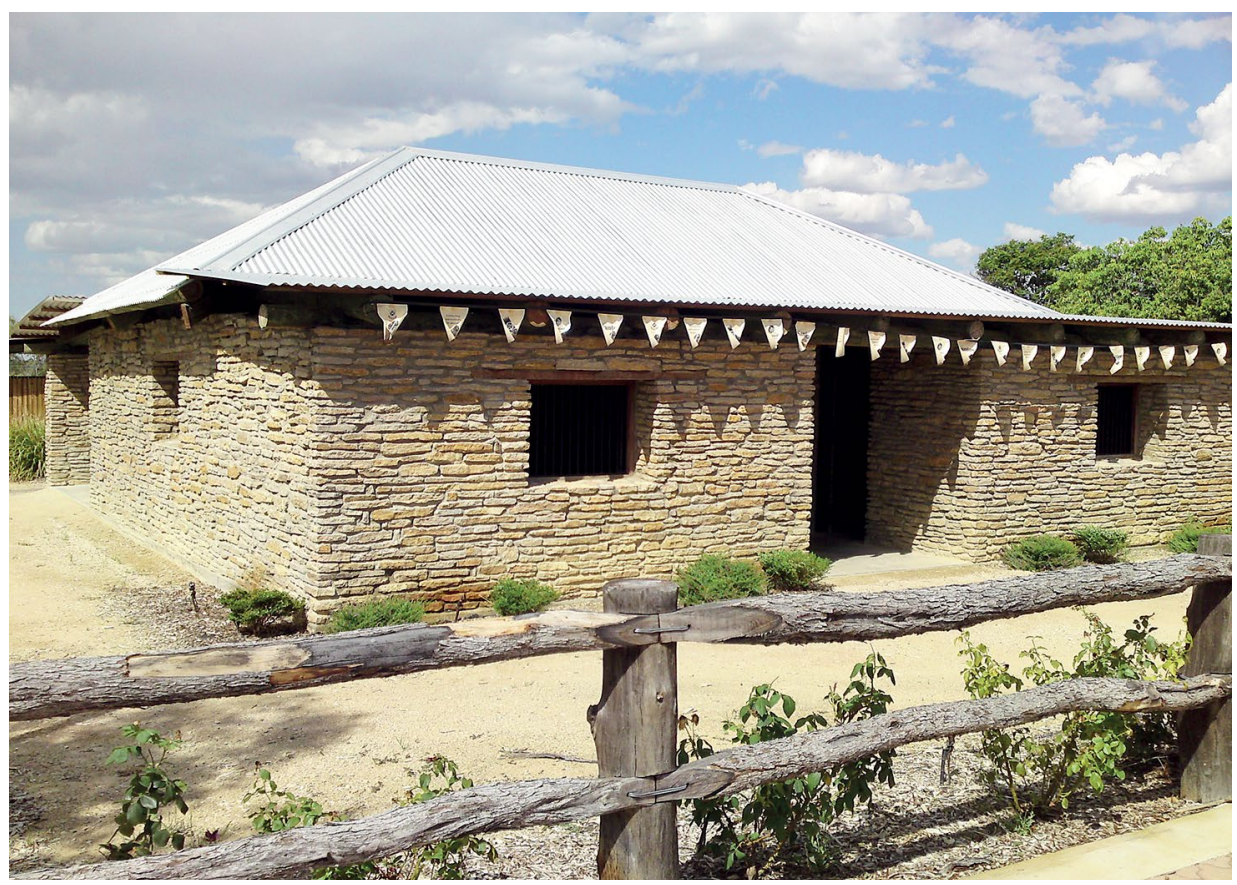

Figure 3: Cambridge Downs Heritage Display Centre, Richmond, 2010.

Source: Photograph by Kerry Martin.

Both versions present the stone homestead, which later served as a post office and store, as a symbol of the tenacity and perseverance of pastoral settlers, demonstrating the value of the community's pastoral heritage and this property in particular.

This interpretive material provided at the homestead replica ${ }^{5}$ is based primarily on a local history of the Richmond Shire written in 1995 by Julie Ann Authurs for the Richmond Shire Council. Authurs was not a historian and, at the time of writing, had only recently arrived in the Richmond community. Her work derived largely from unpublished notes prepared by a local amateur historian, Tom Staunton (now deceased), that were held by the council. Staunton had spent time in the Queensland State Archives and other repositories, ${ }^{6}$ but his work is unreferenced. As such, the claims that he, and subsequently Authurs, made for the Cambridge Downs homestead can be assumed to reflect a locally accepted version of history only. The version published by Tourism and Events Queensland is similarly unreferenced, but probably derives from Authurs's work. None of the details in either version have been traced to other primary sources. In this paper, we analyse this local (and presumably largely oral and possibly quite modern) history of the Cambridge Downs structure in terms of the process of public history-making in Richmond.

5 Richmond Shire Council n.d. (b).

6 Taylor 2013: 4. 
While the story of fortification attached to the Cambridge Downs homestead cannot currently be considered anything other than 'folklore', we are only partly concerned with whether or not the Cambridge Downs homestead could have been built for defensive purposes, and more with why the telling of such a story has arisen and been perpetuated in the present. This interest derives from a larger project to document the archaeology of the Queensland Native Mounted Police (NMP), one strand of which focuses on an examination of purported defensive elements in settler architecture across the state. The material remnants of the Cambridge Downs homestead provide an opportunity to question the dominant history of Richmond and its pastoral past, and evaluate whether the construction choices evidenced in this unusual building could have been an intentional response to anxieties about frontier violence or merely a functional outcome driven by other factors that were later reinterpreted in this way.

We first evaluate the settlement of Cambridge Downs against the background of Indigenous-European contact in the region and specifically the nature and scale of potential frontier violence. We then consider Cambridge Downs's architecture against the form and nature of other homesteads in order to understand whether or not it was unusual for its time and place. Finally, given the form and location of Cambridge Downs homestead, we consider the connections between the cyclical nature of histories of frontier conflict and arguments for the fortification of settler structures in order to explore wider issues surrounding the ways in which the past is - and has been - remembered.

\section{Cambridge Downs and frontier violence}

In the early 1860s, squatters settled the Kennedy and Burke pastoral districts, occupying large runs on a leasehold basis. ${ }^{7}$ The first account of violence in the region was recorded in 1861 by former Queensland NMP Sub-Inspector Frederick Walker, when a party of approximately 30 Aboriginal men in the vicinity of the Stawell River was fired on by Walker's exploring party. As a result, 'Twelve were killed, and few if any escaped unwounded ... The gins and children had been left camped on the river and as there was no water there our possession of the spring was no doubt the cause of the war'. ${ }^{8}$ Walker's reactions were no doubt influenced by his long history with the NMP, but pastoralists were also active in the process of maintaining a zone of violent encounter.

\footnotetext{
$7 \quad$ Allingham 1988: 47; Bolton 1972: 27; Meston 1895; Towner 1962.

8 Walker, Frederick, 'Diary of Expedition', 30 October 1861, Journal 1861-62, Unpublished manuscript NLA MS23, National Library of Australia.
} 
Cambridge Downs was first settled in 1864 when Kennedy and MacDonald took up land on the north side of the Flinders River. ${ }^{9}$ In 1865, John Lamont Dow, then working on Cambridge Downs, sent locks of hair and an accompanying letter to his father, an extract of which was published in The Ballarat Star. Dow described finding the hair amongst:

things which we got in a black's camp the other day, upon the occasion of a hostile descent, which it was found necessary to make upon about 300 of them, as a lesson for some of their tricks they had been playing upon one of the out-stations. ${ }^{10}$

Dow had been sent to the Gulf country as part of a sponsored exploration group and was one of the first Europeans in the area. ${ }^{11}$ Although he did not elaborate upon either the degree of hostility in this encounter or the nature of the 'lesson', a second letter by Dow in reply to criticism expanded upon this event:

A shepherd came in one night from one of the out camps with a spear in him; his hut had been burnt by the blacks, and he almost killed. Volunteers were called for next morning by one of the owners of the station. Three of us who were engaged in shearing sheep at the Head Camp at the time, went with him, together with a black boy as tracker, overtook them on the open plains, got luckily between them and their war implements, gave them what you may suppose they would get from five men well armed and well mounted, burned about a dray load of nulla nullas, spears, coolamens [sic], \&c. ${ }^{12}$

Only four years later, the unstocked Cambridge Downs property was offered for sale and at that date consisted of a manager's house, woolshed, huts and yards. ${ }^{13}$ The property remained unsold and was abandoned by the end of 1869 , one of nearly 160 properties to be abandoned in the Burke District alone. ${ }^{14}$ At the beginning of 1872, when the Queensland economy was experiencing financial recovery, Cambridge Downs was purchased by William Greig and Francis Nash. ${ }^{15}$ Over the next five years, Greig and Nash embarked on a program of improvement, such that by 1877 the property consisted of:

a substantial dwelling house, bachelors' quarters, kitchen, store, and meat-house, woolshed (capable of holding 130 bales wool), three men's huts, stockyards, horse paddock, and eleven out-stations with huts and yards complete. ${ }^{16}$

\footnotetext{
9 Palmer 1903: 127.

10 Dow 1865a: 2.

11 Dow 1972.

12 Dow 1865b: 2.

13 Advertising, Sydney Morning Herald, 8 March 1869: 6.

14 'Telegraphic', Brisbane Courier, 26 October 1869: 2.

15 Loos 1982: 53; May 1984: 125; 'Official notifications', Brisbane Courier, 13 May 1872: 3.

16 Classified advertising, Queenslander, 19 July 1879: 67.
} 
Tensions with Indigenous people appear to have remained after reoccupation and restocking; as late as 1875, a Chinese shepherd, Ah Shong, was allegedly murdered by Indigenous people. ${ }^{17}$ The presence of the NMP throughout the region in the 1870 s is a further indication of conflict. The NMP were a crucial force in race relations throughout the nineteenth century, a critical component of colonial strategy and the main colonising instrument across all new mining and pastoral districts in Queensland. Their role was to 'disperse' Indigenous people ahead of new settlement and intimidate through constant patrol in areas that were already established, as well as act as a punitive force for local settlers. ${ }^{18}$ The first NMP camps in the Burke region were established in 1865 at Burketown, patrolling as far as the Flinders River, and 1868 at Cloncurry. ${ }^{19}$ Later camps were established throughout the 1870 s, including at Hughenden in 1870, Oak Park and Mt Emu Plains in 1872, Saxby River in 1874, Cornish Creek in 1875, Betts Gorge and Diamantina River in 1876, and on the Burke River near Boulia in 1878 (see Figure 2).$^{20}$ Between 1877 and 1878, there were NMP detachments stationed on Richmond Downs, the neighbouring run just south-east of Cambridge Downs that later became Richmond. ${ }^{21}$ Indigenous people began to be 'let in' to stations from the end of 1874 , so it is possible that the end of the 1870s marked the end of the period of greatest conflict. Equally likely, however, is that violence endured under the guise of working and labour conditions, since it was still used as a means of control to make Aboriginal people comply with pastoralists' conditions. ${ }^{22}$ Moreover, studies from the Kimberley have suggested that violence against Aboriginal people on pastoral frontiers tended to last much longer than on other frontiers, and often well into subsequent decades. ${ }^{23}$

No known contemporary oral history accounts amongst either Aboriginal or nonAboriginal people reference the frontier violence that occurred in the region in the 1860 s or 1870 s. Within the Aboriginal community there is only one primary massacre narrative. This relates to the reprisals that followed the spearing of Henry Kaye, a white officer of the NMP, on the Woolgar goldfields (to the north-east of Cambridge Downs) in $1881 .{ }^{24}$ Although there is no documentary record to confirm the events that followed, local anecdotal evidence suggests that men, women and

\footnotetext{
17 Queensland State Archives Inquest File JUS/N48, 1876.

18 Bottoms 2013: 18.

19 'Progress', Queenslander, 15 August 1868: 11; 'The poor blacks', Brisbane Courier, 26 May 1868: 3.

20 Richards 2008: 30.

21 Pugh's Almanac 1878: 111; 1879: 109. These entries, although referring only to 'troopers' rather than 'native troopers', reflect a pattern of at least one sub-inspector with large numbers of troopers, but no constables. Constable was the term applied to white police, whereas trooper was a term almost solely applied to the NMP (Richards 2008: 11). Pugh's Almanac contains references to several such places, some of which are known NMP camps, so those with 'troopers' are highly likely also to be NMP.

22 Loos 1982: 36, 57.

23 Harrison 2007.

24 Pers. comm. from Allan Kynuna (now deceased) to Lynley Wallis, 2004; pers. comm. from Frank Crapp (now deceased) to Lynley Wallis, 2004.
} 
children of three distinct Indigenous groups were murdered in retaliatory attacks. ${ }^{25}$ Similarly, a local man, Frank Crapp (a descendent of miners on the Woolgar goldfield), recounted that, prior to Kaye's death, Aboriginal people had been spearing bullocks, but no component of his story connected explicitly to violence against settlers, nor to any events before $1881 .{ }^{26}$ The fact that Kaye's death and its possible consequences constitute the seminal frontier violence story for the region means that there are no contemporary Aboriginal counter-narratives around the form or purpose of the Cambridge Downs homestead.

\section{Defensive architecture on the pastoral frontier}

White settlers on the frontier faced certain challenges within a climate of relentless pastoral expansion, aggressive defence of life and property and highly racist attitudes towards Aboriginal people - particularly 'wild' people who had no established relationships with Europeans. Historian Lyndall Ryan has argued that the task in this context is to understand the 'weight of fear and the imaginary that seem to be ever present', that may have influenced settlers' choices about personal safety, how to control their anxieties and the appropriate responses to real and potential threats. ${ }^{27}$ The underlying hypothesis for such a connection - indeed for connections between threat and frontier violence in many forms - is that stimuli that threaten personal safety produce anxiety responses, together with a high motivation for defence that can be manifested in anger and increased potential for attack on those seen as the perpetrators. ${ }^{28}$ Historian Joanna Bourke distinguished between fear and anxiety, where fear refers to 'an immediate, objective threat, while anxiety refers to an anticipated, subjective threat'. ${ }^{29}$ In this light, features of domestic structures that may be evidence of fortification speak to an anxiety underlying life on the frontier and the subjective nature of an anticipated attack. ${ }^{30}$

In an archaeological and architectural context, some studies have argued that settler anxiety was manifested in features that fortified domestic dwellings and outbuildings against Aboriginal attack. Karen Burns, an architect with interests in Australian frontier housing, examined dwellings and barns around Port Phillip in Victoria and along the valleys of the Ouse and Clyde Rivers near Swanport on Tasmania's east coast. She argued that a suite of defensive features were incorporated into these structures. Drawing on Tasmanian accounts from the 1830s, Burns argued that

\footnotetext{
25 Authurs 1995: 203.

26 Queensland State Archive ID number 348676 Coronial Inquest file into death of Henry Pollock Kaye; pers. comm. from Frank Crapp (now deceased) to Lynley Wallis, 2004.

27 Ryan 2013: 222. See also Morris 1992, who argued for a 'culture of terror' created around the European perception of the unpredictability and arbitrariness of Aboriginal resistance.

28 Rogers 1983.

29 Bourke 2003: 126.

30 See also Ryan 2013.
} 
features such as 'portholes' (small openings), roofs covered in turf and solid log wall construction were no accident and that such choices embodied 'a performance of a desired frontier'. ${ }^{31}$ While acknowledging that a fortified building could have a dual function depending on circumstance, Burns argued that these buildings were models for potential action and 'built as symbolic talismans to ward off harm'. ${ }^{32}$ Unfortunately, throughout her study, and despite her architectural background, Burns failed to question whether such features could be accounted for equally well by purely prosaic or functional purposes. Assuming a fortified function therefore resulted in a somewhat circular argument. In contrast, Peter Bell, a historian with expertise in built structures, when examining the inclusion of vertical ventilation slits in a stone barn in South Australia that had purportedly been built for defensive purposes, noted that such openings were common ventilation devices within the English 'bank barn' design. ${ }^{33}$

Nicolas Grguric, a historical archaeologist, examined in some detail three pastoral structures in South Australia built in the 1840s and 1850s and one in the Northern Territory built in the 1870s. All of these were of stone construction and Grguric argued that a number of features may have been used to fortify them. These included 'embrasures' (in one case these were small square openings, at least one of which was closed by wooden shutters, in the other, vertical slits), the minimisation of window size and the absence of windows in rear and side walls..$^{34}$ Grguric also considered alternative explanations. In line with Bell's argument, Grguric conceded that embrasures may have been simply to provide ventilation in outbuildings. ${ }^{35}$ He acknowledged that the typical vernacular stone cottage style imported from Britain and widely used across South Australia was typified by blind rear and side walls unless access to rear out-buildings was required. ${ }^{36}$ Because of this uncertainty, both Grguric's and Burns's evidence remained ambiguous: apertures, embrasures and stone walls could have functioned effectively as defensive features, particularly when incorporated into homesteads, but may equally have been non-defensive, particularly when incorporated into outbuildings.

\section{The Cambridge Downs homestead}

The ruins of the stone building at Cambridge Downs represent the remains of the first permanent homestead built on the site. Although descriptions of the property in 1869 identified a manager's house, there can be no certainty that this is the stone

\footnotetext{
31 Burns 2010: 77.

32 Burns 2010: 73.

33 Bell 1987: 10; see also Grguric 2008: 71; Whittaker 2001.

34 Grguric 2008, 2010.

35 Grguric 2008: 71.

36 Grguric 2008: 282-85.
} 
building on site today. ${ }^{37}$ Greig's and Nash's improvements between 1872 and 1877 resulted in a 'substantial dwelling house', which may be the stone house. ${ }^{38}$ Certainly, data for the Burke census district indicate no stone houses in 1876, but four in 1881 (Table 1), corroborating the likelihood that the Cambridge Downs house was constructed between 1876 and 1877 .

Table 1: Stone houses across census districts in northern, western and far northern Queensland, 1864-86.

\begin{tabular}{|l|c|c|c|c|c|c|}
\hline Census district & 1864 & 1868 & 1871 & 1876 & 1881 & 1886 \\
\hline Kennedy North & 0 & 0 & 2 & 0 & 6 & 3 \\
\cline { 1 - 5 } Kennedy South & 0 & & 0 & 0 & & \\
\hline Mitchell & 0 & 19 & 1 & --- & --- & --- \\
\hline Burke & --- & 0 & 0 & 0 & 4 & 2 \\
\hline Gregory & --- & $5 *$ & --- & --- & --- & --- \\
\hline Townsville & --- & 0 & 0 & 0 & 1 & 1 \\
\hline Cook & --- & 0 & 0 & 0 & 0 & 0 \\
\hline Cardwell & --- & 0 & 0 & 0 & 1 & 1 \\
\hline Gilbert & --- & --- & 0 & --- & --- & --- \\
\hline Somerset & --- & --- & --- & 1 & --- & --- \\
\hline Palmer & --- & --- & --- & 3 & --- & --- \\
\hline Etheridge & --- & --- & --- & 0 & 2 & 0 \\
\hline Woothakata & --- & --- & --- & --- & 0 & 1 \\
\hline Cloncurry & --- & --- & --- & --- & --- & 2 \\
\hline Hughenden & --- & --- & --- & --- & 1 \\
\hline
\end{tabular}

*Specified as 'huts'

Source: Queensland Registrar General's Office 1865: 96; 1869: 40; 1872: 258; 1877: 14; 1882: 27; 1887: 31.

Authurs suggested that, during the 1880s and 1890s, the original stone homestead was transformed into a post office and store, although a store was already present by 1878 and post office functions had been transferred to the property in $1875 .{ }^{39}$ It may well be that both functions were formerly located elsewhere on the property, but shifted to the stone house when a newer homestead (now demolished) was constructed in the late nineteenth century. Former owner Ian McClymont described the stone homestead as being constructed of 'flagstones and mud with iron bars in the windows', and Authurs further elaborated this description:

37 Sydney Morning Herald, 8 March 1869: 6.

38 Classified advertising, Queenslander, 19 July 1879: 67.

39 Authurs 1995: 267-68; 'Postal affairs at the Flinders', Queenslander, 3 April 1875: 9. 
The original Cambridge Homestead had a cane grass roof, flagstone floor and one inch bars in the windows. The cooking was done in a separate building adjacent with a large stone oven. Water would have been carted from the adjacent creek. The homestead was situated out in the open downs away from trees in case of raids by hostiles. Later on when galvanised iron became available, the roof was then constructed of that. ${ }^{40}$

The floor plan shows a structure with five rooms: a large central room that spans the width of the building flanked by two rooms on the north at the rear and two on the south at the front (Figure 4). The central room had a hipped roof, but the southern rooms were built under a separate skillion. These two rooms are small and separated by a short length of hallway that functioned as an entrance lobby, with external access off the lobby. The walls are made from roughly coursed sandstone slabs with an average thickness of $300 \mathrm{~mm}$. Each of the front rooms contained a small window measuring approximately $1,000 \times 1,000 \mathrm{~mm}$; a similar window was once also present in the western wall as shown by photographs of the homestead c. 1890 (Figure 5). When recorded in 2010, all structural timbers had collapsed. The front wall was almost complete, but only the lowest sections of the rear, side and internal walls were still intact. In 2016, the building had

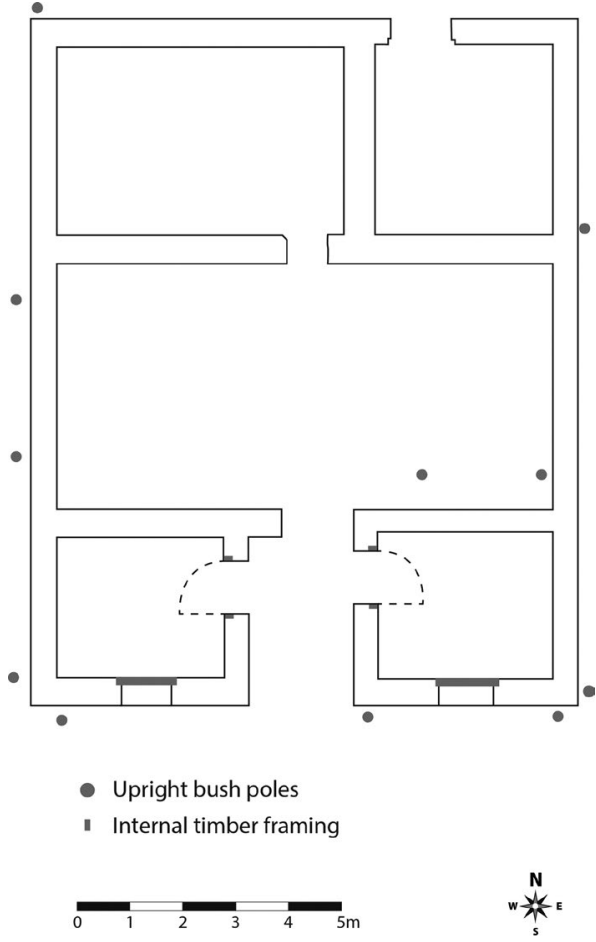

Figure 4: Floor plan of Cambridge Downs homestead, based on archaeological (visible) evidence. Source: Diagram created by authors. deteriorated still further, such that neither of the timber window frames in the southern wall remained in situ. ${ }^{41}$

40 McClymont cited in Authurs 1995: 268; Authurs 1995: 267.

41 Archaeological work at Cambridge Downs in both 2010 and 2016 focused solely on the standing structure itself; systematic surveys were conducted around the homestead to a distance of approximately $1 \mathrm{~km}$ for other archaeological traces of past activities or relationships between Aboriginal people and European settlers that might either confirm or contest the folklore of settler fear and Indigenous hostility. No evidence was located. 
The side walls show no evidence of the homestead having been built in stages, even though the building incorporates at least two separate roof lines. This suggests that the form and layout of the two small southern rooms were contemporary with the construction of the central and rear sections, rather than being enclosed later as additions under a verandah skillion. Like the front two rooms, the rear two rooms may also have been under a skillion roof, although this is not visible in the only known photograph of the homestead (see Figure 5) and no contemporary structural evidence for roofing survives. No glass windows are evident in the historic photograph, but traces of butt hinges on the timbering of the window apertures indicate they were sealed by a single, internal wooden shutter that spanned the width of the window opening (Figure 6). According to Authurs, the windows once had a series of vertical metal bars across the opening, which were removed along with the iron roof following World War II. ${ }^{42}$ There is no surviving structural evidence for bars ever having been present on the windows, or evidence of any damage caused by their removal (for example, the intact timber frames shown in Figure 6). It is possible they sat in the large gap between the timber window framing and the exterior stone walling (Figure 7), but, if so, their installation and removal have left no physical traces on the building.

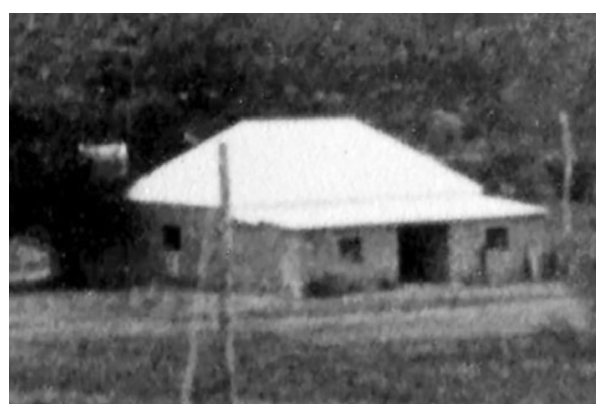

Figure 5: Cambridge Downs homestead, looking north-east, c. 1890.

Source: Courtesy of Richmond Shire Council.

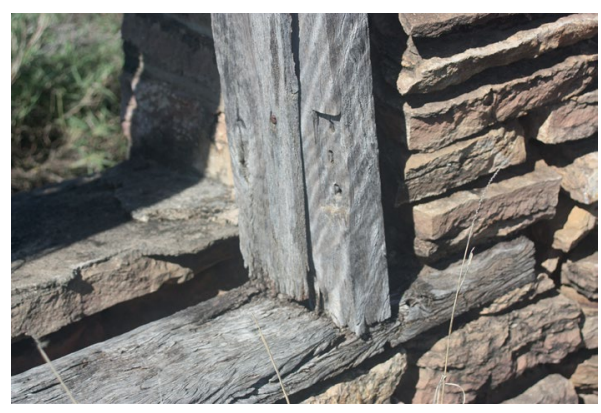

Figure 6: Traces of a butt hinge for an internal timber shutter, in situ window frame, 2010.

Source: Photograph by Matthew Moran.

This layout and form have been reasonably accurately represented in the replica at Richmond (Figure 3) except for the shutters, which were not included in the reconstruction. Instead, the bars are the main feature, inset into the internal timbering of the window apertures rather than the gap between the window frame and the external wall (Figure 8). Other alterations to the replica include a breezeway at the rear to accommodate storage facilities.

42 Authurs 1995: 267. According to one undated source these were removed by tying them to a vehicle and pulling them out, see Burnett 1984/5: 16. 


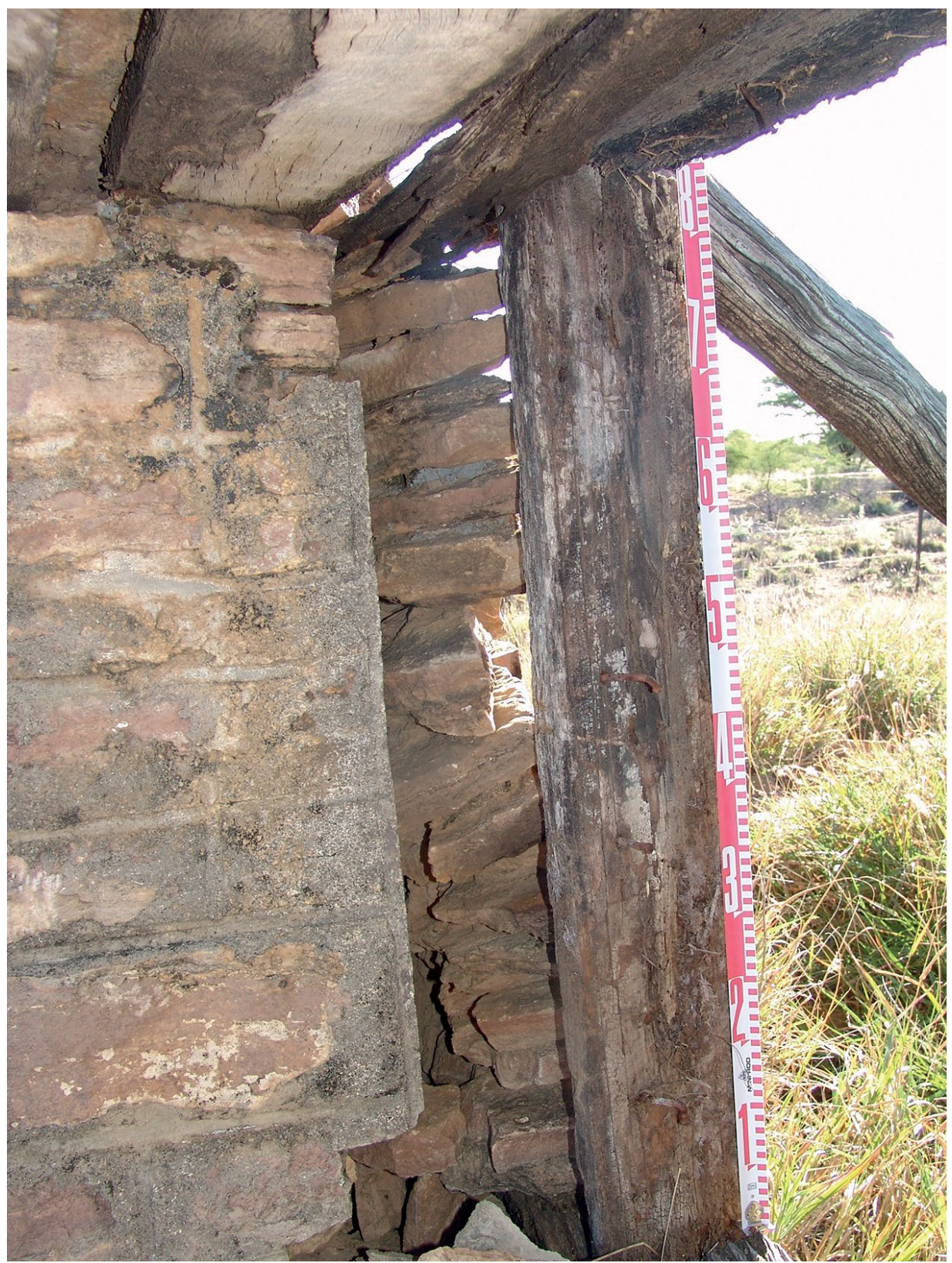

Figure 7: Gap between window frame and stone wall, western front room, 2016. It is possible that bars once sat in this gap, but there is no visible, physical evidence.

Source: Photograph by Heather Burke. 


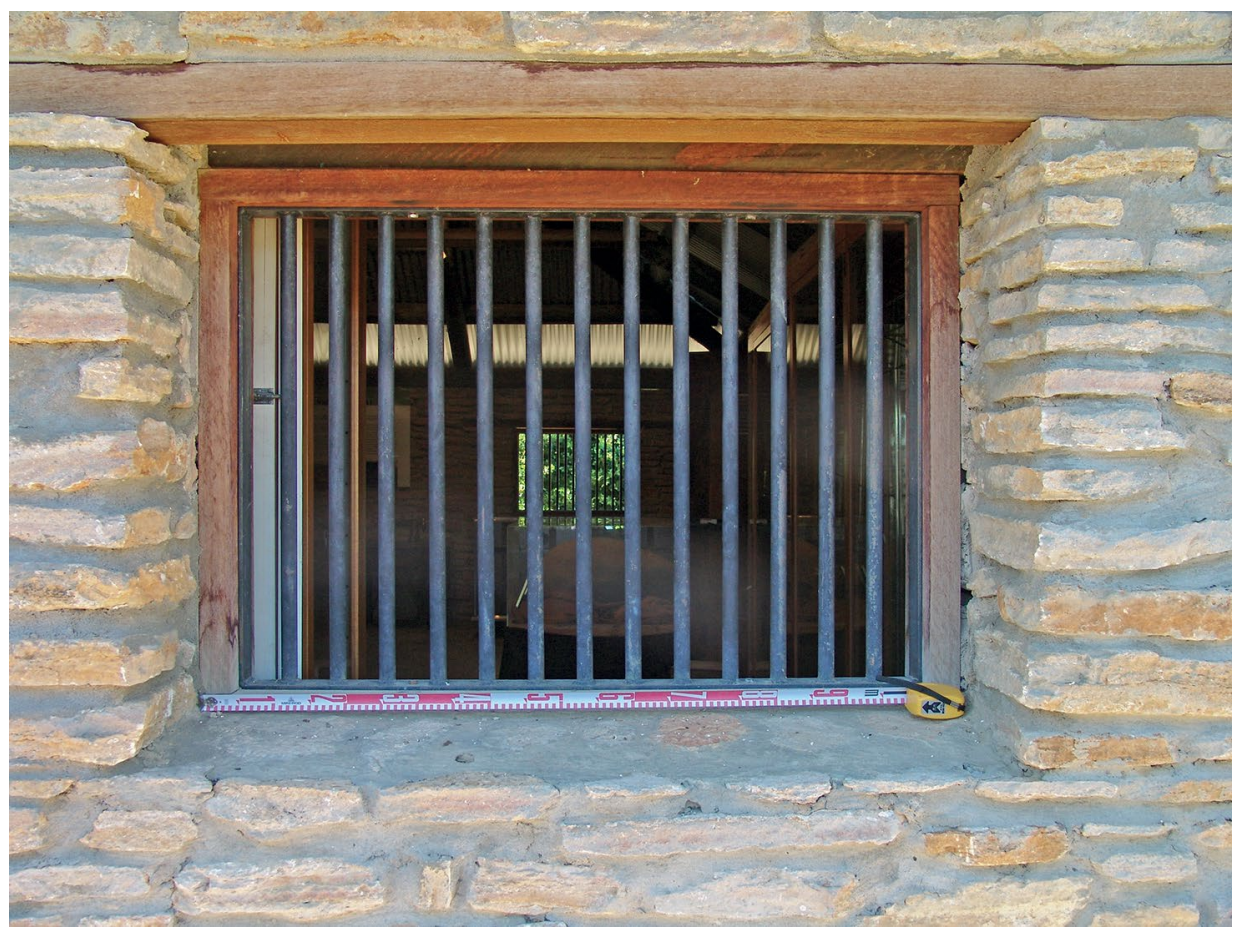

Figure 8: Bars set into the timber window framing of the replica Cambridge Downs homestead, Richmond.

Source: Photograph by Heather Burke.

\section{Comparing Cambridge Downs}

The early use of stone in building construction is certainly unusual, although not unheard of, in the Burke District. Sumner used census data from 1861 and 1864 to demonstrate a complete absence of stone/brick homesteads in the Kennedy District, east of the study area. ${ }^{43}$ A similar pattern is evident in the Burke District, with no stone houses appearing in the census data until 1881, by which time there are four (Table 1). The lack of stone might be attributable to several factors: timber was often more readily available and required less skill to build with; ${ }^{44}$ stone required at least some skill with masonry - the construction of the Elderslie homestead complex, for example, in the early 1880s near Winton, was the result of a serendipitous combination of a German stonemason hailing from South Australia and the abundant supply of local sandstone from Mount Booka-Booka; ${ }^{45}$ and climatic conditions meant that greater ventilation and cooling was achieved by timber construction. ${ }^{46}$

43 Sumner 1974: 49.

44 Bell 1984: 119; Sumner 1974: 55.

45 Cultural Heritage Branch and the Queensland Heritage Council 2005: 33.

46 Bell 1984: 13; Sumner 1974: 56. 
Stone dwellings, however, were invulnerable to rot or termite attack. Variations in building techniques as a result of previous experience and cultural background were also likely. For example, mud bricks were used to construct a dwelling on the banks of the Flinders River at Hughenden and pisé homesteads were particularly predominant in the channel country. ${ }^{47}$ Mud was also used as a matrix to bind rubble or flagstones, examples of which exist at Lammermoor and Richmond (The Mud Hut Hotel). ${ }^{48}$

For Cambridge Downs, the stories of fortification are attached to the fact that it is built with thick stone walls, the two front (southern) rooms have small windows, and is said to have had bars on the windows. The thick stone construction certainly meant that the walls would have been difficult to penetrate in an attack. However, walls constructed of heavy timber slabs, corrugated iron or mud and timber/rubble would be equally impermeable and sufficient for resisting attack. Further, stone walls need to be thick enough to support the weight of the roof. Some authors have suggested that the use of stone is ill-suited to the north Queensland climate, ${ }^{49}$ but a ready supply, masonry skills and ability or aesthetic preference may all have been contributing factors in the decision to construct in stone, as at Elderslie. Although there is some suggestion that the bars were originally part of the windows, there is no physical evidence of their presence. If they were present, it seems equally likely that they might have been installed when the building was converted to a post office and store, at which time a greater level of security may have been appropriate, an event Authurs claimed took place in the 1880s/1890s. While the use of wooden shutters was a common security device in early settler buildings, they were also essential in areas that relied on dray transport and where the successful transportation of glass panes would have been expensive and difficult at best. ${ }^{50}$

Beyond Cambridge Downs, other homesteads in the region also have stories of fortification attached to them. Old Westmoreland homestead, also built in stone by 1881 near the Northern Territory-Queensland border, was located in an area with many documented instances of violence. ${ }^{51}$ The Queensland Heritage Register's statement of cultural heritage significance for this site states:

The building shows clear evidence of being constructed with due consideration for possible conflict: thick walls (which would also have helped insulate the building), inward opening doors, and few windows. ${ }^{52}$

47 Sumner 1974: 51-52.

48 Sumner 1974: 52; see also Sorenson 1911.

49 Bell 1984.

50 Cox and Lucas 1978: 31, 76; Freeland 1988: 71

51 Roberts 2005.

52 Gray 1913: 130. 
Anthropologist Richard Martin also noted 'the tiniest window slits built into the sides' of the homestead as a means of protection, although this observation has no source. ${ }^{53}$ The first homestead at Lammermoor (south-east of Hughenden) was built from heavy gidyeah slabs in a log hut style, which one contemporary observer described as 'a substantial and neatly erected log hut with loopholes for rifles'. ${ }^{54}$

Cambridge Downs homestead was certainly built sturdily and from materials that are unusual in its geographic context, but it does not necessarily follow that this was a consequence of anxiety resulting from life on an uncertain and sometimes violent frontier. This conclusion oversimplifies our understanding of the building since there were possibly several other factors that influenced the choice of construction style and materials. On the balance of present data, and unlike the Queensland Heritage Register entry, we argue that there is no 'clear evidence' of Cambridge Downs having been fortified: there is only scant evidence of conflict on or near the property, the methods of construction are consistent with traditional principles of stonemasonry in vernacular contexts, the use of shutters can be explained as a purely functional, non-defensive choice and the window bars, if present, may well have added at a later date as part of a change in use. The fact that such ambiguity is inherent in both this and the only other previous studies of fortified structures that we are aware of causes us to question such arguments more widely. ${ }^{55}$

\section{The homestead as fortress: Fact or furphy?}

The fact that there are stories about the homestead being fortified is perhaps of greater relevance to an understanding of frontier conflict than the physical structure itself. Historical references to frontier violence, perpetrated by both settlers and Aborigines, are so numerous that it would be difficult to deny either that an atmosphere of dread and anxiety must have existed on the frontier, or that many more violent encounters took place than can be deduced from documentary records alone. Frontier anxiety would have been widespread, but it is not clear that all settlers responded in the same fashion, otherwise there would presumably be a greater number of similar dwellings, as well as dwellings that were undisputably fortified as the telegraph stations on Cape York Peninsula were. ${ }^{56}$ Instead, the fact that Cambridge Downs is a reasonably rare example of architecture in a region where the nineteenthcentury pastoral dwelling was typified by a slab hut has likely contributed to its intrigue. In a community whose identity centres around pastoralism and pioneering endeavour - of which frontier conflict has been an integral, although probably

\footnotetext{
53 Martin 2012: 13.

54 Gray 1913: 130; Bennett 1928; also Sumner 1974: 48-52.

55 Burns 2010; Grguric 2008, 2010.

56 White 1918. These buildings, such as that which survives as the Musgrave River roadhouse today, had turrets on opposing corners specifically included in the design for defence against attacks.
} 
unspoken, part - it is not difficult to understand how the homestead has come to both symbolise and perpetuate local lore. It is not inconceivable, then, that the fortification of Cambridge Downs homestead is a subsequent, and probably highly localised, folkloric construct rather than direct evidence of inter-racial conflict and violence during the expansion of the pastoral frontier in the nineteenth century.

The contemporary story of Cambridge Downs is now principally filtered through its replica in the main street of Richmond. This is often the only version encountered by visitors, since the original homestead is located 30 kilometres out of town and is not a major tourist locale. The fact that the signage at the modern replica contains no accredited source for the fortification story has not prevented it from becoming taken for granted; in fact, its representation in the replica's official interpretive signage has given it a degree of authenticity that is only bolstered by the physical presence of the bars on the windows as the material embodiment of protection. A lack of sources is typical of the circulation of such knowledge as self-evident tradition within a local community, the recording of it in secondary local histories as established fact and the resurrection of it in subsequent accounts built upon this foundation, often with little or no regard for the veracity of the links in the chain. ${ }^{57}$ The historical sequence for the property - instances of Aboriginal-settler violence in the 1860s, the initial construction of a homestead in stone c. 1876 and its possible subsequent conversion to a store and/or post office when a new homestead was built, possibly in the $1880 \mathrm{~s}$ - is collapsed into a single set of decisions made in response to an external threat, and the visitor invited to imagine what that must have been like as they look through the bars at the world outside. In many ways, the account of fortification that has been built around the Cambridge Downs homestead ties into earlier and still persistent strands of local history-making across settler nations, since such tales of frontier structures enhance visions of 'ordinary' people as battlers and pioneers fighting for their personal safety. The attacks that such architecture was intended to deter are on domestic spaces, and often on the sacrosanct spaces of family, women and children. Furthermore, such accounts tell only the non-Aboriginal side of the story and are therefore automatically cast as stories of protection and as choices that were defensive (and therefore implicitly justified), rather than offensive.

\section{Conclusion}

The 'flattening' of history that folklore achieves obscures alternative interpretations and elides events to present a modern politics of the frontier. The US research by Anne Yentsch that we drew attention to in the opening of our paper has highlighted the folklore of frontier violence and used it to map the construction of history at a community or 'folk' level. In examining later folk history accounts for what were

57 For a similar chain, see Roberts's $(1995,2003)$ analysis of the story of the Bells Fall massacre near Sofala. 
deemed to be 'odd' architectural features, such as narrow staircases, high windows or small, downward-facing openings in upper storeys, Yentsch recorded a series of explanations that linked them to resisting attack from hostile Native Americans: narrow staircases prevented attacking parties from ascending in groups, allowing them to be killed one by one, small openings allowed people with guns to fire on those below and high windows were built to prevent arrows being shot into houses. In this process, she noted that houses acquired symbolic connotations as icons of superior strength and intellect that could be used to demonstrate the superiority of one group over another as part of a general process of myth-making:

Like tombstones, houses serve as historical records set in the landscape. The history of a house is the history of a family or a sequence of families ... Created as mythology, the legends wrapped around houses operated according to principles of mythological thought, obeying a logic (encountered cross culturally) wherein normal boundaries of time and space, the real and the non-real, were differently manipulated than in the rational thought guiding day to day activity. ${ }^{58}$

Trying to determine whether or not such accounts are 'true' is far from simple and, perhaps, in the end, not all that useful. There are two poles to the debate over the contribution that local and oral histories can make to the historical understanding of frontier conflict: one is that increasing chronological distance confers a greater degree of honesty in the telling; the other is that local and oral accounts become more mythologised and less reliable over time. ${ }^{59}$ Historians Harris, Nettelbeck and Foster, for example, noted that 'unrecorded events and community memories' are often curated for long periods within local communities, so much so that they argue that local stories of violence at Elliston, South Australia, have survived for more than 150 years within non-Indigenous memory. ${ }^{60}$ Notably, however, they provided no evidence for the historical continuation of such memories across this time span, and did not interrogate the stories, their sources or their genealogies. On the other hand, several other scholars have pointed to the invention of detail, reworking of events and transference of elements between stories that occur as tales are filtered through successive tellers. ${ }^{61}$ Moreover, Indigenous oral histories appear to work differently. Deborah Bird Rose has noted that the further events recede from the present, the more speakers focus on intentions rather than events. She refers to this as faithfulness rather than truthfulness, since the facts become malleable in this space, although the purpose of the stories still centres on the meaning of what happened. This faithfulness represents for her 'the moral content of the process of colonization'. ${ }^{62}$

58 Yentsch 1988: 6-7.

59 Ryan 2010: 269; Wilson and O'Brien 2003.

60 Harris 2003: 89; Nettelbeck 2011: 1118; Nettelbeck and Foster 2010: 53.11-53.12.

61 For example Roberts 1995, 2003; Wilson and O’Brien 2003.

62 Rose 2003: 125. 
Stories of violence attached to homesteads and domestic spaces are obviously highly ideological in that they legitimise particular constructions of historical processes and demonstrate the superiority of white settlers over Indigenous people. In the same way that stories of the white pastoralists who perpetrated violence on the Queensland frontier became stories of 'pastoral pioneers' in later reinventions of their activities, we would argue that stories about houses that cast them as defensible structures function similarly and may also have been invented and attached to buildings at a later date. This does not make them any less meaningful, however. Like other aspects of pioneer myth, 'however fanciful they became, [they are] testament to the desire to remember, at least among those regional communities most affected by the resonances of frontier violence'. ${ }^{63}$ Moreover, there have been cycles of willingness to believe in such stories, arising in response to different political and social contexts and articulating different ideologies and anxieties. ${ }^{64}$ Regardless of whether the stories are true in any original sense, people's willingness to believe in them is real, in the process revealing the cycles of response to Aboriginal people.

Shifting the story into the centre of town via the auspices of the replica has served to solidify the fortification story, in that the bars are present and incontrovertible, and disseminate its meanings to a much wider travelling audience. As such, the building has come to symbolise the pioneering spirit and endeavour that is an integral part of the pastoral heritage and identity of the region and casts this in a particular light, while at the same time remaining mute on the violence inflicted by settlers and the NMP on Aboriginal people during the process of settlement. Riggs has argued that a fundamental catalyst within contemporary political relationships between Indigenous and non-Indigenous Australians is the unsettling effects of the 'anxieties of whiteness' that are still managed through the projection of threat on to Indigenous people. ${ }^{65}$ Like Riggs and Augoustinos, we do not argue here that the choice to represent Cambridge Downs as a fortified structure in local histories and public interpretation is necessarily a motivated act, but that its representation exists within wider, contemporary ideological frameworks that position Aboriginal and non-Aboriginal people in particular ways for particular purposes. ${ }^{66}$

What is required next is further careful and nuanced study of the content, genealogies and uses of oral and local histories of fortification attached to frontier structures and an analysis of their 'faithfulness' in Rose's sense. Raymond Evans contended that ' $[\mathrm{h}]$ istorians have yet to construct a cartography of the selective trails of remembrance and forgetting in Australia's past'. ${ }^{67}$ We would argue that this applies not just to actual tales of a violent encounter, but also to imagined ones,

63 Foster 2009: 68.12.

64 Roberts 1995, 2003.

65 Riggs 2003: 95.

66 Riggs and Augoustinos 2004.

67 Evans 2010: 13. 
since the degree to which, and ways in which, folklore circulates can indicate how people negotiate their relationship between past, present and future. Folklore - or collective memories of things that may or may not have happened - flourishes in the gaps between lines of evidence and is not necessarily a function of 'untruth'. Instead, it can be a dynamic and meaningful way to create individual and collective relationships to place, as well as 'imagined, predicted or anticipated futures' for groups of people. ${ }^{68}$ In this way, folk history becomes a vehicle for building communities at the local level, connecting the past with the present in immediate, and often family-based, ways.

Stories of domestic fortification and defence are part of a long tradition of representing Aboriginal agency as a threat. Without a critical evaluation of each structure and the genealogy of oral historical accounts of fortification attached to them we have no way to separate the 'weight of fear and the imaginary' on the frontier in the past from the ways in which such claims have been used subsequently to remember or forget the consequences of the frontier in the present. The patterning of anxiety, fear, inclination, violence and response becomes uniform rather than contextual to particular places, regions, people or choices. Moreover, tales of individual structures, like monuments, 'allow only brief statements [and] do not tell the complex story of curiosity, resistance, dispossession, accommodation, isolation, and politicization which characterized the racial frontier in Australia'. ${ }^{69}$ Critical evaluation of both individual fortified domestic structures and patterns of fortification (whether real or imagined) across regions, families or time periods may begin to unravel some of the complexity of this story both then and now, and contribute to understanding the anxieties that continue to underlie cultural inter-relations in contemporary Australia.

\section{Acknowledgements}

This paper derives from Australian Research Council Discovery Project DP160100307, 'The Archaeology of the Queensland Native Mounted Police'. We would like to thank Rob Koch, Jacqueline Matthews, Hayley Heffernan, Tim O'Rourke and the University of Queensland architecture students who assisted with fieldwork at the site. We are especially grateful to Peter Todd for discussions of vernacular architecture, assistance with fieldwork and other encouragement. Thanks also to the referees and editor, whose thoughtful comments have enhanced our final paper.

68 Szpunar and Szpunar 2016: 385.

69 Bulbeck 1991: 177. 


\section{References}

\section{Primary sources}

Justice Department, Queensland 1876, Depositions and findings in coroners' inquests, Queensland State Archives Item ID348647, Inquest file, 58, JUS/N48.

\section{Newspapers}

Geelong Advertiser

The Brisbane Courier

The Catholic Press

The Register (Townsville)

The Queenslander

The Sydney Morning Herald

\section{Government publications}

Queensland Registrar General's Office 1865, Second Census of the Colony of Queensland, Taken on the 1st January 1864, Government Printer, Brisbane, hccda.ada.edu.au/documents/ (accessed 21 October 2016).

1869, Third Census of the Colony of Queensland, Taken on the 2nd March 1868, Government Printer, Brisbane, hccda.ada.edu.au/documents/ (accessed 21 October 2016).

1872, Census of 1871, Taken on the 1st Day of September, Being the Fourth Taken in the Colony, Government Printer, Brisbane, hccda.ada.edu.au/documents/ (accessed 21 October 2016).

— 1877, Fifth Census of Queensland 1876, Government Printer, Brisbane, hccda. ada.edu.au/documents/ (accessed 21 October 2016).

1882, Sixth Census of the Colony of Queensland Taken on the Third April 1881, Government Printer, Brisbane, hccda.ada.edu.au/documents/ (accessed 21 October 2016).

1887, Seventh Census of the Colony of Queensland, Taken on the First of May 1886, Government Printer, Brisbane, hccda.ada.edu.au/documents/ (accessed 21 October 2016). 


\section{Published sources}

Allingham, Anne 1988, 'Taming the Wilderness': The First Decade of Pastoral Settlement in the Kennedy District, Studies in North Queensland History No. 1, History Department, James Cook University, Townsville.

Authurs, Julie Ann 1995, From Wyangarie to Richmond: An Historic Record of the Richmond District of North Queensland, Richmond Shire Council, Richmond, Qld.

Bell, Peter 1984, Timber and Iron: Houses in North Queensland Mining Settlements, 1861-1920, University of Queensland Press, St Lucia.

— 1987, 'Post-colonisation Heritage Study of Glenthorne CSIRO Field Station', unpublished report for the National Trust of SA.

Bennett, Mary Montgomerie 1928, Christison of Lammermoor, second edition, Alston Rivers, London.

Bolton, Geoffrey 1972, A Thousand Miles Away: A History of North Queensland to 1920, Australian National University Press, Canberra.

Bottoms, Timothy 2013, Conspiracy of Silence: Queensland's Frontier Killing Times, Allen \& Unwin, Sydney.

Bourke, Joanna 2003, 'Fear and anxiety: Writing about emotion in modern history', History Workshop Journal 55: 111-33. doi.org/10.1093/hwj/55.1.111.

Bulbeck, Chilla 1991, 'Aborigines, memorials and the history of the frontier', Australian Historical Studies 24(96): 168-78. doi.org/10.1080/ 10314619108595878.

Burnett, R. 1984/5, 'Silence settles on outpost. Ruins evidence of early settlement', Register, August 30: 16-17.

Burns, Karen 2010, 'Frontier conflict, contact, exchange: Re-imagining colonial architecture', in Imagining: Proceedings of the 27th International SAHANZ Conference, M. Chapman and M. Ostwald (eds), Society of Architectural Historians, Australia and New Zealand, Newcastle, NSW: 70-80.

Cox, Philip and Clive Lucas 1978, Australian Colonial Architecture, Lansdowne Editions, Melbourne.

Cultural Heritage Branch and the Queensland Heritage Council 2005, Illustrated Guide to Entering Houses in the Queensland Heritage Register, Environmental Protection Agency, Brisbane. 
Dow, Hume 1972, 'Dow, John Lamont (1837-1923)', in Australian Dictionary of Biography, National Centre of Biography, The Australian National University, adb.anu.edu.au/biography/dow-john-lamont-3433/text5227, published first in hardcopy 1972 (accessed 14 January 2017).

Dow, John L. 1865a, 'News and notes', Ballarat Star, 13 May: 2.

1865b, 'A word with Mr Jenkins', Letter to the Editor, Geelong Advertiser, 16 September: 2.

Evans, Ray 2010, 'The country has another past: Queensland and the History Wars', in Passionate Histories: Myth, Memory and Indigenous Australia, Frances PetersLittle, Anne Curthoys and John Docker (eds), ANU E Press, Canberra: 9-38.

Foster, Robert 2009, “'Don't mention the war": Frontier violence and the language of concealment', History Australia 6(3): 68.1-68.15.

Freeland, John Maxwell 1988, Architecture in Australia: A History, Pelican, Victoria.

Gray, Robert 1913, Reminiscences of India and North Queensland, Constable and Company Ltd, London.

Grguric, Nicholas 2008, 'Fortified Homesteads: The Architecture of Fear in Frontier South Australia and the Northern Territory, ca 1847-1885', unpublished PhD thesis, Department of Archaeology, Flinders University, SA.

_ 2010, 'Staking a claim: Fortified homesteads and their place in Australian settler identity construction', Archaeological Review from Cambridge 25: 47-63.

Harris, John 2003, 'Hiding the bodies: The myth of the humane colonisation of Aboriginal Australia', Aboriginal History 27: 79-104.

Harrison, Rodney 2007, 'Materiality, "ambiguity" and the unfamiliar in the archaeology of inter-societal confrontations: A case study from northwest Australia', in Encounters, Materialities, Confrontations: Archaeologies of Social Space and Interaction, Per Cornell and Fredrik Fahlander (eds), Cambridge Scholars, Newcastle, UK: 42-57.

Loos, Noel 1982, Invasion and Resistance: Aboriginal-European Relations on the North Queensland Frontier, 1861-1897, Australian National University Press, Canberra.

Martin, Richard J. 2012, 'Representing "The Gulf": Issues of Place, Race and Identity in a Region of Northern Australia', unpublished PhD thesis, School of Social and Cultural Studies, University of Western Australia. 
May, Dawn 1984, 'The north Queensland beef cattle industry: An historical overview', in Lectures on North Queensland History No. 4, B.J. Dalton (ed.), James Cook University, Townsville: 121-59.

Meston, Archibald 1895, Geographic History of Queensland, Government Printer, Brisbane.

Morris, Barry 1992, 'Frontier colonialism as a culture of terror', Journal of Australian Studies 16: 72-87. doi.org/10.1080/14443059209387119.

Nettelbeck, Amanda 2011, 'The Australian frontier in the museum', Journal of Social History 44(4): 1115-28. doi.org/10.1353/jsh.2011.0047.

Nettelbeck, Amanda and Robert Foster 2010, 'Commemorating foundation: A study in regional historical memory', History Australia 7(2): 53.1-53.18.

Palmer, Edward 1903, Early Days in North Queensland, Angus and Robertson, Sydney.

Pugh, Theophills P. 1878, Pugh's Queensland Almanac, Law Calendar, Directory, Coast Guide, and Gazetteer for 1878, William Thorne, Brisbane.

— 1879, Pugh's Queensland Almanac, Law Calendar, Directory, Coast Guide, and Gazetteer for 1879, William Thorne, Brisbane.

Richards, Jonathan 2008, The Secret War: A True History of Queensland's Native Police, University of Queensland Press, St Lucia.

Richmond Shire Council n.d. (a), A Brief History of the Richmond Shire, Richmond Shire Council, Richmond, Qld.

— n.d. (b), Cambridge Downs Heritage Display Centre Interpretive Board, Richmond Shire Council, Richmond, Qld.

Riggs, Damien 2003, 'Repressing a privileged location: Exploring the uncanniness of white belonging', Analysis 12: 83-98.

Riggs, Damien and Martha Augoustinos 2004, 'Projecting threat: Managing subjective investments in whiteness', Psychoanalysis, Culture and Society 9(2): 219-35. doi.org/10.1057/palgrave.pcs.2100020.

Roberts, David 1995, 'Bell Falls massacre and Bathurst's history of violence: Local tradition and Australian historiography', Australian Historical Studies 26(105): 615-33. doi.org/10.1080/10314619508595986. 
2003, 'The Bells Falls massacre and oral tradition', in Frontier Conflict: The Australian Experience, Bain Attwood and Stephen G. Foster (eds), National Museum of Australia, Canberra: 150-57.

Roberts, Tony 2005, Frontier Justice: A History of the Gulf Country to 1900, University of Queensland Press, St Lucia.

Rogers, Ronald W. 1983, 'Cognitive and physiological processes in fear appeals and attitude change: A revised theory of protection motivation', in Social Psychophysiology: A Sourcebook, John T. Cacioppo and Richard E. Petty (eds), Guilford Press, New York: 153-76.

Rose, Deborah 2003, 'Oral histories and knowledge', in Frontier Conflict: The Australian Experience, Bain Attwood and Stephen G. Foster (eds), National Museum of Australia, Canberra: 120-31.

Ryan, Lyndall 2010, 'Settler massacres on the Port Phillip frontier, 1836-1851', Journal of Australian Studies 34(3): 257-73. doi.org/10.1080/14443058.2010. 498091.

2013, 'Untangling Aboriginal resistance and the settler punitive expedition: The Hawkesbury River frontier in New South Wales, 1794-1810', Journal of Genocide Research 15(2): 219-32. doi.org/10.1080/14623528.2013.789206.

Sorenson, E.S. 1911, 'Backblock homes and builders: The architecture of the pioneer', Catholic Press, 13 April: 5.

Sumner, Ray 1974, 'Pioneer homesteads of north Queensland', in Lectures on North Queensland History, Brian J. Dalton (ed.), James Cook University, Townsville: 47-61.

Szpunar, Piotr and Karl Szpunar 2016, 'Collective future thought: Concept, function and implications for collective memory studies', Memory Studies 9(4): 376-89. doi.org/10.1177/1750698015615660.

Taylor, Victor Jean 2013, 'The Woolgar Goldfield's Industrial Archaeology of Capitalism 1879-1939', unpublished PhD thesis, School of Archaeology and Anthropology, The Australian National University, Canberra.

Tourism and Events Queensland n.d., 'Factsheet 28: "What was Life Like During the 1800s for the Pioneer Settlers of the Outback?"', teq.queensland.com/enAU/Destinations/Outback-Queensland/Outback-Education-Subsidy-Scheme/ Student-Factsheets (accessed 13 March 2015).

Towner, A.C. 1962, 'An outline of the history of western Queensland', Journal of the Royal Historical Society of Queensland 6(4): 779-816. 
Walker, Frederick 1862, 'Diary of Expedition', unpublished manuscript NLA MS23, National Library of Australia.

White, Gilbert 1918, Thirty Years in Tropical Australia, Society for Promoting Christian Knowledge, London.

Whittaker, Tim 2001, 'The bank barns of Cumbria', Journal of the Historic Farm Buildings Group 15: 4-64.

Wilson, Bill and Justin O’Brien 2003, “'To infuse a universal terror”: A reappraisal of the Coniston killings', Aboriginal History 27: 59-78.

Yentsch, Anne 1988, 'Legends, houses, families, and myths: Relationships between material culture and American ideology', in Documentary Archaeology in the New World, Mary Beaudry (ed.), Cambridge University Press, Cambridge: 5-19. 
This text is taken from Aboriginal History, Volume 41, 2017, edited by Ingereth Macfarlane, published 2017 by ANU Press, The Australian National University, Canberra, Australia.

dx.doi.org/10.22459/AH.41.2017.07 